Society. Several other term pregnancies following ventrofixation may be found in current literature and some have not yet been published. As the discussion on Mr. Mayo Robson's excellent paper was adjourned I need not further detail these. One may, however, warrantably claim that a considerable number of women suffering from fixed retro- flexion of the uterus have been not only relieved from all the attendant symptoms and disabilities, but have been restored to complete sexual health, permitting normal pregnancy, as the result of this conservative operation. I am, Sirs, yours faithfully,

Grosvenor-street, W., March 23rd, $1896 . \quad$ LEITH NAPIER.

\section{THE SCHOTT TREATMENT OF HEART DISEASE.}

To the Editors of THE LAXCET.

SiRs, - In common no doubt with many of your readers I have been greatly interested in the communications to your columns dealing with the Schott methods for the treatment of heart disease. I fear the cases and commentary communicated to THE LANCET of March 21st by Dr. Kingscote will hardly serve to dispel that absolute and obstinate incredulity of which he complains.

The impression conveyed from the brief account of the cases is that they might have improved considerably on quite ordinary lines of treatment. In most of the cases there is little evidence that the cardiac dilatation was due to organic valvular disease. We are not told that any of the patients had had acute rheumatism, and in no case is there mention of cedema, a symptom reasonably to be expected where failure of accommodation is at all extensive. Case $1 \mathrm{had}$ albuminuria due, it was thought, to "defective circulation," a vague phrase, which might mean aortic disease or a tendency to chilblains. In this patient slight dilatation was detected with difficulty on one occasion and was promptly cured. In one case only a systolic bruit was noted. Are we to suppose that in the other cases auscultation revealed nothing abnormal? Percussion is the method of examination Dr. Kingscote mostly relies upon, and I fear he values this method far too highly, for he has seen a heart diminish its boundaries two inches in all directions in fifteen minutes. Would it not be safer to say that the area of cardiac dulness diminished?

I do not know whether the Roentgen rays have yet illumined the thorax, or whether the thoracic viscera could be so displayed, but pictures of such a heart, other than percussion charts, would be interesting. Dr. Kingscote tells us that the treatment acts by raising the blood-pressure in the arteries and so relieving the surcharged heart. If this be so it is difficult to understand why the treatment is of value in gout and chronic Bright's disease, where the hypertrophied heart dilates in consequence of the high arterial tuension. I am, Sirs, yours faithfully,

Leicester, March 23rd, 1896.

T. V. CrosbY, M.B. Lond.

\section{"TORSION OF OVARIAN PEDICLE IN HERNIAL SAC."}

To the Eaitors of THE LANCET.

SIRs,-I am interested to see that Mr. Owen bas met with another case of hernia of the ovary with torsion of the pedicle. His case is similar to mine, except that the infant wis eleven weeks old, whilst mine was six months. The brief record, to which Mr. Owen alludes, was merely an abstract if the paper which I read upon my case. I hope soon to put all the facts of this rare event on record.

$$
\text { I am, Sirs, yours truly, }
$$

C. B. LockWOOD.

Upper Berkeley-street,' Portman-square, W., March 24th, 1896.

\section{"THE CASE OF MR. LIONEL SMITH." \\ To the Editors of 'I'HU LANCE'T.}

SiRs, - We beg to report that up to the present we have received the sum of $£ 17913 s$. $6 d$. on behalf of $\mathrm{Mr}$. H. Lionel Smith. The amount is quite inadequate to meet the demands upon him for the support and education of his whildren, and his salary as district medical officer at Rorke's
Drift is barely sufficient to provide for the needs of himself and wife. We need hardly recapitulate the harsh treatment that Mr. Lionel Smith received at the hands of the Government of Western Australia; how, on being unjustly dismissed from his post, he gained two actions against the Government; and how he was finally beaten on a technical point on appeal to the Privy Council after ruinous litigation. It is proposed to close the subscription list at the end of this month, but we hope that some others of your readers will even now come to the rescue of a man whose career has been blighted through no fault of his own.

We are, Sirs, yours faithfully,

JAMES F. GOODHART,

F. DE HaViliand Hatl.

P.S.-We append a list of subscriptions recently received.
Mr. Launcelot Newton
Dr. W. H. Brazi
$\ldots £ 1 \quad 1 \quad 0$
C. E. C.
.... 1

\section{"SUBCUTANEOUS EMPHYSEMA OCCURRING DURING LABOUR."}

\section{To the Editors of THE LANCET.}

SIRS,--This accident, referred to in THE LANCET of March 14th and 21st, is a somewhat rare one. I recollect when I was house surgeon of the Royal Maternity Hospital, Edinburgh, about 1874, attending a primipara in the hospital. No ergot was used and the labour did not appear unusually severe. I think the emphysema was not noticed till an hour or two after complete delivery, and it then extended over the face, neck, and thorax. It entirely subsided in three or four days. I showed the case to the late Dr. Alezander Keiller, lecturer on midwifery, \&c., Surgeons' Hall, and honorary physician to the hospital, and although he had a very large experience $I$ think he said he had never met such a case before. Since then I have never seen or heard of a similar case. I am, Sirs, yours truly, Jersey, March 22nd, 1896

$$
\text { LL MOFAT, M.D., C.M. St. And. }
$$

\section{POOR-LAW OFFICERS' SUPERANNUATIUN BILL. \\ To the Editors of THE LANCET.}

SIRs,-I am a Poor-law medical officer for a district containing a poor population of 5000 scattered over an area of 15,000 acres, the nearest point being one mile and the furthest six miles. My pay averages about $9 d$. a visit and $6 l$. for a week's supply of medicine. The income-tax under Schedule $\mathrm{E}$ deducts $8 d$, in the pound and the proposed compulsory superannuation contribution will deduct another $6 d$. in the pound. I am forty-two years of age and, according to tables, my expectation of life is twenty-four years-i.e., I shall probably reach sixty-six. In return for this extra reauction of $6 a$. in the pound per annum for the next twenty three years I have a chance of one year's pension, but if I die in the meanwhile what benefit shall I or my representatives derive from this deduction from my already inadequate pay? I am, Sirs, your obedient servant, March 23rd, 1896. A COUNTRY PARISH DOCTOR.

\section{"ASSISTANTS."}

To the Editors of THE LANCET.

SiRs,-Perhaps your correspondent who describes himself as "A Sorely-tried Principal," and who has chosen to publicly vilify those of his professional colleagues who may be (through no fault of their own) unable to acquire practices of their own, forgets that there is another side to the shield. What of principals who are petty snobs and tyrants? What of those who meanly grind their assistants down to starvation wages? What of those who invariably get rid of a man if he bids fair to become more popular than his principal? What of the man who, fixed in the therapeutical traditions of his perhaps long-past student days, scouts modern notions as unpractical and new-fangled, himself an inveterate laudator temporis acti? However, it would be as absurd to say that all principals come under the above heads as it would be to suppose that the thirteen assistants of your correspondent are a lair sample of their class, or, indeed, 